\title{
Erosion-induced massive organic carbon burial and carbon emission in the Yellow River basin, China
}

\author{
L. $\operatorname{Ran}^{1}, X \cdot X \cdot \mathbf{L u}^{1,2}$, and Z. Xin ${ }^{3}$ \\ ${ }^{1}$ Department of Geography, National University of Singapore, 117570 Singapore \\ ${ }^{2}$ College of Environment \& Resources, Inner Mongolia University, Hohhot, 010021, China \\ ${ }^{3}$ Key Laboratory of Soil and Water Conservation and Desertification Combating of the Ministry of Education, \\ Beijing Forestry University, Beijing, 100083, China
}

Correspondence to: X. X. Lu (geoluxx@nus.edu.sg)

Received: 25 July 2013 - Published in Biogeosciences Discuss.: 14 August 2013

Revised: 9 January 2014 - Accepted: 9 January 2014 - Published: 20 February 2014

\begin{abstract}
Soil erosion and terrestrial deposition of soil organic carbon (SOC) can potentially play a significant role in global carbon cycling. Assessing the redistribution of SOC during erosion and subsequent transport and burial is of critical importance. Using hydrological records of soil erosion and sediment load, and compiled organic carbon (OC) data, estimates of the eroded soils and OC induced by water in the Yellow River basin during the period 1950-2010 were assembled. The Yellow River basin has experienced intense soil erosion due to combined impact of natural process and human activity. Over the period, $134.2 \pm 24.7 \mathrm{Gt}$ of soils and $1.07 \pm 0.15 \mathrm{Gt}$ of OC have been eroded from hillslopes based on a soil erosion rate of $1.7-2.5 \mathrm{Gt} \mathrm{yr}^{-1}$. Approximately $63 \%$ of the eroded soils were deposited in the river system, while only $37 \%$ were discharged into the ocean. For the OC budget, approximately $0.53 \pm 0.21 \mathrm{Gt}(49.5 \%)$ was buried in the river system, $0.25 \pm 0.14 \mathrm{Gt}(23.5 \%)$ was delivered into the ocean, and the remaining $0.289 \pm 0.294 \mathrm{Gt}(27 \%)$ was decomposed during the erosion and transport processes. This validates the commonly held assumption that $20-40 \%$ of the eroded OC would be oxidized after erosion. Erosion-induced OC redistribution on the landscape likely represented a carbon source, although a large proportion of OC was buried. In addition, about half of the terrestrially redeposited OC $(49.4 \%)$ was buried behind dams, revealing the importance of dam trapping in sequestering the eroded OC. Although several uncertainties need to be better constrained, the obtained budgetary results provide a means of assessing the redistribution of the eroded OC within the Yellow River basin. Human activities have significantly altered its redistribution pattern over the past decades.
\end{abstract}

\section{Introduction}

As one of the most active mechanisms controlling soil formation and evolution, soil erosion affects not only the translocation of soil materials, but also the dynamics of organic carbon (OC) and nutrients, such as nitrogen and phosphorus. The $2300 \mathrm{Gt}$ of carbon (C) stored in global soil is 3 times the size of the atmospheric $\mathrm{C}$ pool and 4.1 times the biotic $\mathrm{C}$ pool (Lal, 2003). Soil erosion in terrestrial ecosystems is therefore capable of influencing global $\mathrm{C}$ redistribution among the five strongly interrelated $\mathrm{C}$ pools, with the other two pools being the oceanic and geologic $\mathrm{C}$ pools. Quantifying carbon transport within each pool or exchange between different pools is of key importance for refining the understanding of carbon cycles at different scales.

Owing to difficulties in constraining the $\mathrm{C}$ source/sink strength at erosional and depositional sites, the impact of soil erosion on carbon cycling has not been well documented. Prior estimates of the portion of soil organic carbon (SOC) oxidized during soil erosion and sediment transport range from $0 \%$ to almost $100 \%$ (Smith et al., 2001; Cole and Caraco, 2001; Lal, 2003; Van Hemelryck et al., 2011). With varying carbon oxidation rates, the global soil erosion process has been described both as a net $\mathrm{C}$ source of around $1 \mathrm{Gt} \mathrm{yr}^{-1}$ (Lal, 2003) and a net $\mathrm{C}$ sink of up to $1.5 \mathrm{Gt} \mathrm{yr}^{-1}$ (Stallard, 1998). It is clear that the fate of SOC mobilized by erosional processes remains largely unknown. Rivers represent important conduits of carbon from terrestrial ecosystems to the oceans and the atmosphere (Cole et al., 2007; Battin et al., 2009; Aufdenkampe et al., 2011). Studying river transport of the eroded OC plays a critical role in understanding carbon cycle at the watershed level. 


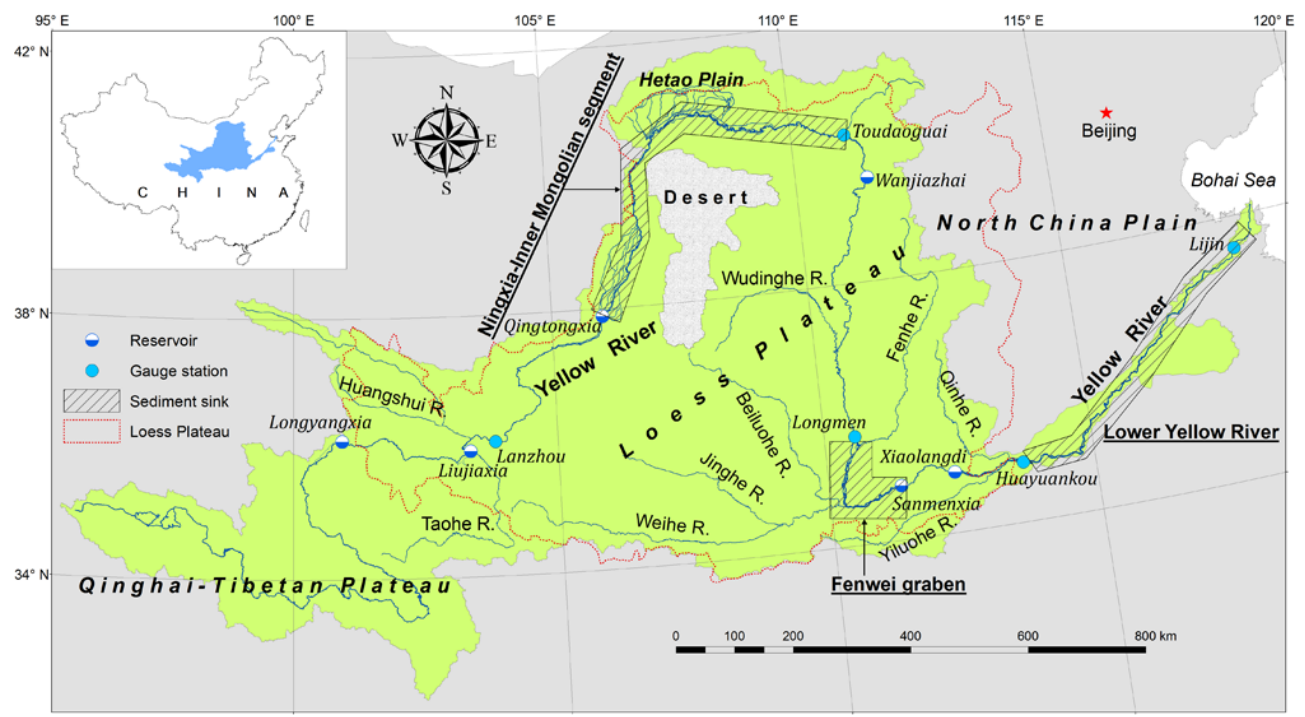

Fig. 1. Location map of the Yellow River basin showing major hydrological gauge stations, reservoirs, and sediment sink zones.

Although numerous studies have attempted to analyze the Yellow River's sediment dynamics at a sub-basin scale, systematic assessment of its basin-wide sediment budget taking into account both natural transport and anthropogenic impact is lacking. Furthermore, despite the fact that preliminary studies on the transport of $\mathrm{OC}$ in world rivers have been documented, Asian rivers, which alone contribute about $40 \%$ of global sediment flux, have not received sufficient attention in terms of OC transport (Schlünz and Schneider, 2000). Given such high sediment fluxes, it is expected that the OC fluxes of Asian rivers will be substantial. For the Yellow River, there is currently a great gap in knowledge regarding its sediment and OC cycles. Understanding these cycles may have global implications given its intense soil erosion and high sediment flux. Several investigations concerning OC cycling in the Yellow River show that most of the OC is transported as particulate $\mathrm{OC}$, while the dissolved fraction accounts for less than $10 \%$ of the total $\mathrm{C}$ flux due to its high sediment load and relatively low water (Cauwet and Mackenzie, 1993; Gan et al., 1983; Zhang et al., 1992). Therefore, analyzing the redistribution of the particulate fraction after erosion could provide insights into understanding the basin-wide OC cycling.

The aim of this study is to provide estimates of the OC redistribution on the landscape and the amount of decomposed OC induced by soil erosion within the Yellow River basin during the period 1950-2010. This long time period allows us to analyze human impacts on the watershed-scale OC cycle because significant human activities have occurred over the period. Due to the great difference between rates of soil erosion and river transport (Walling and Fang, 2003), an advantage of this study is that we estimated the amounts of erosion, sedimentation, and transport independently to derive a sediment budget. In contrast to conventional methods that usually use models, we estimated the eroded OC redistribution and decomposition in proportion to soil erosion and sediment deposition through the established sediment budget.

\section{Study area}

The Yellow River flows from its origin in the QinghaiTibetan Plateau along a $5464 \mathrm{~km}$ course towards eastern China, passing through the Loess Plateau and the North China Plain and finally emptying into the Bohai Sea (Fig. 1). With a drainage area of $\sim 752000 \mathrm{~km}^{2}$, the basin is characterized by a continental climate, ranging from humid climates in the SE section to subarid climates in the central region to arid climates in the NW section. The annual mean precipitation decreases from $700 \mathrm{~mm}$ in the southeast to $250 \mathrm{~mm}$ in the northwest, and several heavy storms in the wet season can account for $>70 \%$ of the annual total precipitation (Zhao, 1996).

During the period 1950-2010, mean annual water discharge at Lijin was $30.8 \mathrm{~km}^{3} \mathrm{yr}^{-1}$, and the mean annual sediment flux was $0.74 \mathrm{Gt} \mathrm{yr}^{-1}$ (Ministry of Water Resources of China, 2010a). The spatial sources of water and sediment are quite different. While about $60 \%$ of the water is supplied by the upper reaches (Zhao, 1996), nearly $90 \%$ of the sediment originates from the Loess Plateau in the middle reaches (Hassan et al., 2008) (Fig. 1). As the river flows over the alluvial plains, huge amounts of sediment deposit within the channel or on the floodplains, raising the channel bed above the surrounding land at a rate of $8-10 \mathrm{~cm} \mathrm{yr}^{-1}(\mathrm{Xu}, 2005$; H. J. Wang et al., 2007). Around 3000 dams have been constructed in the river basin, with $>110000$ silt check dams on the Loess Plateau to intercept sediment (Ran et al., 2013c). Water diversion for irrigation has increased steadily since the 


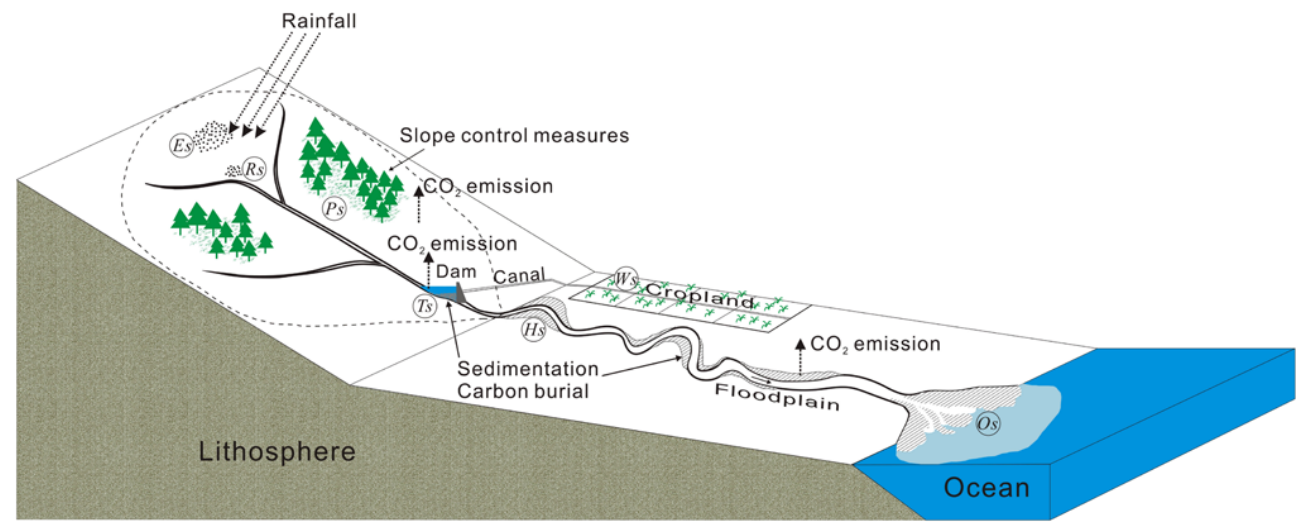

Fig. 2. A conceptual diagram showing production, transport, and deposition of bulk sediment and organic carbon within a river basin, as well as the impact of human activity. The budget terms are explained in the text.

1950s. Two major agricultural areas are the Hetao Plain and the North China Plain (also known as the lower Yellow River basin) (Fig. 1). About $9.55 \mathrm{~km}^{3}$ of water is annually diverted from the lower Yellow River, representing about $25 \%$ of the water discharge at Huayuankou (Qin et al., 2007; Ministry of Water Resources of China, 2010b). Considerable sediment loss has been noted with the withdrawn water (H. J. Wang et al., 2007).

On the Loess Plateau (Fig. 1), The wind-deposited Quaternary loess is usually $130-180 \mathrm{~m}$ thick, up to $250 \mathrm{~m}$ in some localities (Liu et al., 1991). Due to its loose structure and high porosity, the loess is highly susceptible to forces of water, wind, or gravity. Coupled with heavy storms that have strong erosive power, suspended sediment concentrations exceeding $100 \mathrm{~kg} \mathrm{~m}^{-3}$ have been frequently recorded (Zhao, 1996). To mitigate soil erosion, soil conservation measures have been widely implemented. Apart from the silt check dams constructed on gullies, slope soil control measures have effectively protected large quantities of soils from being swept downslope (Fu et al., 2011; Ran et al., 2012). About 20 soil types have been detected on the Loess Plateau. Calcaric Regosols, grey Podzolic soils, and Calcisols are the dominant soil orders, which together cover $\sim 70 \%$ of the total surface area. The SOC in the loess soils is very low, and the SOC pool has been recently increased as a result of continuous vegetation rehabilitation (Chen et al., 2007).

\section{Methods}

\subsection{Conceptual framework}

Soil erosion by water at the basin scale is usually composed of three phases, including detachment, transport, and deposition of soil particles. The detachment occurs at uplands where soil is vulnerable to erosion. The eroded materials are subject to transport and deposition along their course to the ocean (Fig. 2). In the Yellow River basin, all three phases have been affected by humans, mainly through soil control, dam construction, and irrigation withdrawal (Fig. 2).

A simple budget equation for production, transport, and sedimentation of bulk sediment through various transport pathways and depositional terms can be expressed as follows:

$E_{\mathrm{S}}=T_{\mathrm{S}}+H_{\mathrm{S}}+W_{\mathrm{S}}+O_{\mathrm{S}}+P_{\mathrm{S}}+R_{\mathrm{S}}$

where, $E, T, H$, and $W$ represent soil erosion, dam trapping, channel deposition, and water diversion, respectively; and $O$, $P$, and $R$ represent seaward transport, slope soil conservation, and hillslope redistribution, respectively. While $E_{\mathrm{S}}, T_{\mathrm{S}}$, $H_{\mathrm{S}}, W_{\mathrm{S}}, O_{\mathrm{S}}$, and $P_{\mathrm{S}}$ can be directly estimated from available data, $R_{\mathrm{S}}$ is determined as a residual and includes potential errors arising from other sedimentation processes not considered in the budget and the propagation of uncertainty. For a specific channel reach, $H_{\mathrm{S}}$ can be calculated as

$H_{\mathrm{S}}=\sum[$ input $]-\sum[$ output $]-\sum[$ damdiv $]$.

The $\sum$ [input] is the sum of sediment input measured at upstream gauge stations; the $\sum$ [output] is the sum of sediment output measured at downstream gauge stations; and the $\sum$ [damdiv] is the sum of sediment trapped by dams and diverted by canals.

Obviously, $E_{\mathrm{S}}$ is the sediment source, and the terms in the right-hand side of Eq. (1) are the sediment sinks. As $T_{\mathrm{S}}, H_{\mathrm{S}}$, $W_{\mathrm{S}}, P_{\mathrm{S}}$, and $R_{\mathrm{S}}$ represent the sediment deposited within the landscape, and $O_{\mathrm{S}}$ is delivered into the ocean, Eq. (1) can be viewed as the balance between erosion (sediment production) and the sum of the sedimentation terms. It also indicates that bulk sediments are conserved during erosion and sedimentation.

Equivalent to Eq. (1), a similar budget can be written for OC. Unlike the sediment transport, there is an additional flux. A considerable portion of the eroded $\mathrm{OC}$ is labile and is thus vulnerable to decomposition after erosion. The OC 
decomposed to $\mathrm{CO}_{2}$ gas is represented by $D$.

$E_{\mathrm{C}}=T_{\mathrm{C}}+H_{\mathrm{C}}+W_{\mathrm{C}}+O_{\mathrm{C}}+P_{\mathrm{C}}+R_{\mathrm{C}}+D_{\mathrm{C}}$.

Similarly, the decomposed $\mathrm{OC}\left(D_{\mathrm{C}}\right)$ can be determined as a residual between the eroded OC and the deposited OC. As the decomposition fraction $\left(D_{\mathrm{C}}\right)$ is not reflected in the bulk sediment cycle, OC within the basin may not be conserved compared with bulk sediments (Smith et al., 2001).

$E_{\mathrm{C}}$ can be estimated from the eroded soils and their SOC content while taking into account dynamic replacement of in situ SOC over the period, representing the amount available for burial and decomposition. For the Yellow River, both are adequately known in literature. $O_{\mathrm{C}}$ can be determined through the seaward sediment and its OC content. Seaward sediment flux has been continuously recorded for more than $60 \mathrm{yr}$, and the sediment's OC content has also been investigated in recent years (Chu et al., 2009; Ran et al., 2013a). Terms $T_{\mathrm{C}}, H_{\mathrm{C}}, W_{\mathrm{C}}, P_{\mathrm{C}}$, and $R_{\mathrm{C}}$ are not directly known but can be approximated from sediment flux data and the corresponding OC content. Assuming the OC content to be $\theta(\%)$,

$$
\begin{aligned}
& \theta_{E}=\left[\frac{C}{S}\right]_{E} ; \theta_{T}=\left[\frac{C}{S}\right]_{T} ; \theta_{H}=\left[\frac{C}{S}\right]_{H} ; \theta_{\mathrm{W}}=\left[\frac{C}{S}\right]_{\mathrm{W}} ; \\
& \theta_{\mathrm{O}}=\left[\frac{C}{S}\right]_{\mathrm{O}} ; \theta_{P}=\left[\frac{C}{S}\right]_{P} ; \theta_{R}=\left[\frac{C}{S}\right]_{R}
\end{aligned}
$$

where, $C$ and $S$ represent $\mathrm{OC}$ and sediment, respectively. $D_{\mathrm{C}}$ can be solved as a function of the known quantities by rearranging Eqs. (1)-(3):

$$
\begin{aligned}
D_{\mathrm{C}} & =E_{\mathrm{S}} \cdot \theta_{E}-T_{\mathrm{S}} \cdot \theta_{T}-H_{\mathrm{S}} \cdot \theta_{H}-W_{\mathrm{S}} \cdot \theta_{\mathrm{W}} \\
& -O_{\mathrm{S}} \cdot \theta_{\mathrm{O}}-P_{\mathrm{S}} \cdot \theta_{P}-R_{\mathrm{S}} \cdot \theta_{R} .
\end{aligned}
$$

It is clear that $D_{\mathrm{C}}$ depends on the total eroded OC amount available for delivery and the burial rates of the OC associated with sediments (Smith et al., 2001). The difference provides a measure of the eroded OC that is neither buried in the river system nor delivered into the ocean. Data sources of individual terms are specified in Sect. 4.

\subsection{Estimation of uncertainty}

Uncertainties in the quantifiable budget terms were estimated by considering their measurement errors. Particularly, because soil erosion and SOC dynamics have changed greatly over time, their temporal variations were assessed (see Sects. 4.2 and 5.2). With the uncertainties in individual sediment budget terms, we estimated the propagated uncertainty of the hillslope redistribution by treating the errors on the individual terms as being statistically independent, although not entirely true (Smith et al., 2001). This allows us to evaluate its propagation of uncertainty by adding the uncertainties of the individual budget terms in quadrature (Taylor, 1997). Assuming the prefix $\delta$ represents independent error, for the sediment budget, the propagation of uncertainty in $R_{\mathrm{S}}$, expressed as $\delta R_{\mathrm{S}}$, is

$\delta R_{\mathrm{S}}=\sqrt{\left(\delta E_{\mathrm{S}}\right)^{2}+\left(\delta T_{\mathrm{S}}\right)^{2}+\left(\delta H_{\mathrm{S}}\right)^{2}+\left(\delta W_{\mathrm{S}}\right)^{2}+\left(\delta O_{\mathrm{S}}\right)^{2}+\left(\delta P_{\mathrm{S}}\right)^{2}}$.

Likewise, the propagated uncertainty in the decomposed OC $\left(\delta D_{\mathrm{C}}\right)$ can be calculated as follows:

$\delta D_{\mathrm{C}}=$
$\sqrt{\left(\delta E_{\mathrm{C}}\right)^{2}+\left(\delta T_{\mathrm{C}}\right)^{2}+\left(\delta H_{\mathrm{C}}\right)^{2}+\left(\delta W_{\mathrm{C}}\right)^{2}+\left(\delta O_{\mathrm{C}}\right)^{2}+\left(\delta P_{\mathrm{C}}\right)^{2}+\left(\delta R_{\mathrm{C}}\right)^{2}}$.

In addition, because the OC budget was established through sediment budget terms and their respective OC content, we evaluated its uncertainty by taking into account the uncertainties in the sediment budget and in the OC content.

\section{Results}

\subsection{Bulk sediment budget}

\subsubsection{Total soil erosion}

Numerous attempts have been made to quantify the amount of soil erosion induced by water in the Yellow River basin over the past decades using statistical approaches or empirical models, such as the Universal Soil Loss Equation (USLE) (Table 1). While these estimates vary by a factor of 1.5 from $1.7 \mathrm{Gt} \mathrm{yr}^{-1}$ to $2.5 \mathrm{Gt} \mathrm{yr}^{-1}$, most fall in the range of $2.1-2.3 \mathrm{Gt} \mathrm{yr}^{-1}$. We adopted $1.7 \mathrm{Gt} \mathrm{yr}^{-1}$ as the minimum erosion rate and $2.5 \mathrm{Gt} \mathrm{yr}^{-1}$ as the maximum, with a mean of $2.2 \mathrm{Gt} \mathrm{yr}^{-1}$ available for subsequent redistribution. It was expressed as mean \pm (maximum - minimum)/2. That is, the mean erosion rate is about $2900 \pm 540 \mathrm{t} \mathrm{km}^{2} \mathrm{yr}^{-1}$. This indicates the basin is at a moderate erosion level, according to the latest national standards of soil erosion classification that defines the moderate level as the range of 2500 $5000 \mathrm{t} \mathrm{km}^{-2} \mathrm{yr}^{-1}$ (Ministry of Water Resources of China, 2008). In comparison, the mean erosion rate in the Yellow River basin is substantially higher than the global mean value (Reich et al., 2001), and is about tenfold that of the conterminous United States of $317 \mathrm{t} \mathrm{km}^{-2} \mathrm{yr}^{-1}$ (Smith et al., 2001). In total, $134.2 \pm 24.7 \mathrm{Gt}$ of soils have been eroded during the period 1950-2010.

\subsubsection{Sediment deposition within dams and channels}

With a total storage capacity of $72 \mathrm{~km}^{3}$ exceeding the annual water flux, flow dynamics in the Yellow River have been significantly modified by reservoirs (Ran and Lu, 2012). Furthermore, sediment trapping has altered its sediment delivery process (Fig. 3). With the commission of large reservoirs, such as the Liujiaxia Reservoir in 1969, the Longyangxia Reservoir in 1986, and the Xiaolangdi Reservoir in 2000, the sediment load decreased sharply. For instance, in the Sanmenxia Reservoir, located downstream of the Loess Plateau (Fig. 1), about $6.6 \mathrm{~km}^{3}$ of sediment, or $8.6 \mathrm{Gt}$ assuming a bulk 
Table 1. Estimates of soil erosion rate in the Yellow River basin.

\begin{tabular}{|c|c|c|c|c|}
\hline Estimated scale & $\begin{array}{l}\text { Soil erosion } \\
\left(\mathrm{Gt} \mathrm{yr}^{-1}\right)\end{array}$ & Method & Source & Note \\
\hline Yellow River basin & $2.1-2.3$ & Statistical estimation & Chen (1983) & $\begin{array}{l}\text { Sum of hydrological measurements and human- } \\
\text { induced reductions; for the period } 1950-1970 \text { s. }\end{array}$ \\
\hline Yellow River basin & 2.2 & Statistical estimation & Shi (1990) & $\begin{array}{l}\text { Total soil erosion rate in the } 1950 \text { s and took } \\
\text { sediment trapping into account. }\end{array}$ \\
\hline Yellow River basin & 2.23 & $\begin{array}{l}\text { Sedimentological investi- } \\
\text { gation }\end{array}$ & Wang et al. (2003) & $\begin{array}{l}\text { Sum of observed erosion and human acceler- } \\
\text { ated erosion; for the period } 1949-1970 \text { s. }\end{array}$ \\
\hline Yellow River basin & 2.2 & $\begin{array}{l}\text { Remote sensing survey and } \\
\text { field observation }\end{array}$ & $\begin{array}{l}\text { Ministry of Water Re- } \\
\text { sources of China }\end{array}$ & $\begin{array}{l}\text { Based on remote sensing survey conducted in } \\
\text { 1990. Details at http://www.mwr.gov.cn/ztbd/ } \\
\text { huihuang/hh50/chapter9.htm. }\end{array}$ \\
\hline Yellow River basin & 1.7 & Statistical estimation & Li and Liu (2006) & $\begin{array}{l}\text { Reconstruction of the soil erosion rate for the } \\
1950 \text { s. }\end{array}$ \\
\hline Yellow River basin & 1.97 & Statistical estimation & $\begin{array}{l}\text { Y. Wang et } \\
\text { al. }(2010)\end{array}$ & $\begin{array}{l}\text { Averaged for the period 1950-1959 before } \\
\text { large-scale soil conservation. }\end{array}$ \\
\hline Loess Plateau & $2.4-2.5$ & & $\mathrm{Fu}(1989)$ & $\begin{array}{l}\text { The erosion rate ranged from } 2000 \text { to } \\
20000 \mathrm{t} \mathrm{km}^{-2} \mathrm{yr}^{-1} \text { for the period before } \\
1970 .\end{array}$ \\
\hline Loess Plateau & 2.11 & USLE model & Fu et al. (2011) & For the year 2000 \\
\hline $\begin{array}{l}\text { Middle Yellow } \\
\text { basin }\end{array}$ & 1.66 & $\begin{array}{l}\text { Sedimentological investi- } \\
\text { gation and USLE model }\end{array}$ & Jing et al. (1998) & $\begin{array}{l}\text { Reconstruction of the soil erosion in the } 1970 \text { s } \\
\text { by summing hydrological measurements and } \\
\text { human-induced reductions. }\end{array}$ \\
\hline
\end{tabular}

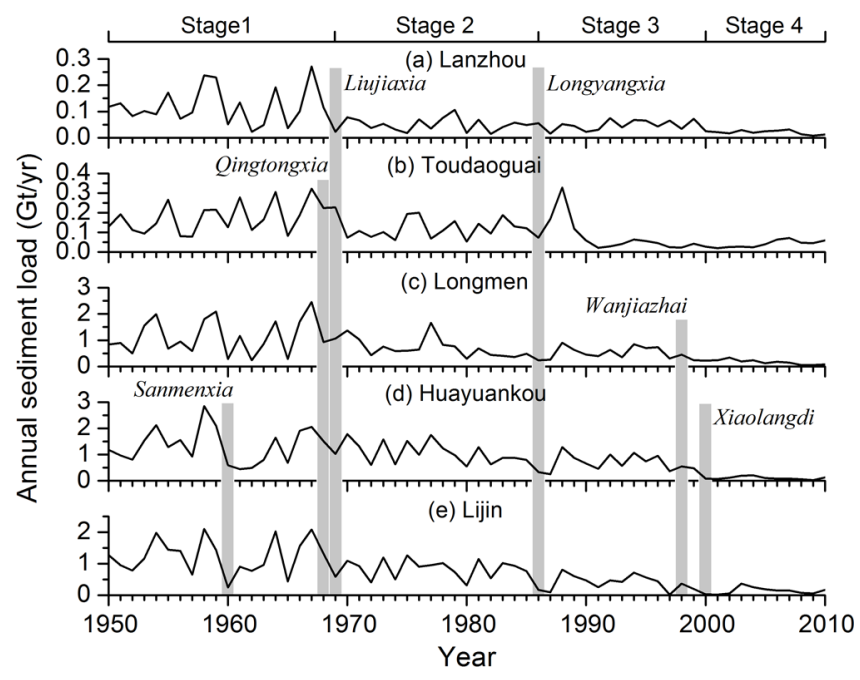

Fig. 3. Temporal variations of sediment load along the mainstem channel: (a) Lanzhou, (b) Toudaoguai, (c) Longmen, (d) Huayuankou, and (e) Lijin. Also shown are large mainstem reservoirs (refer to Fig. 1 for locations). Data are from the Yellow River Conservancy Commission (http://www.yellowriver.gov.cn/).

density of $1.3 \mathrm{t} \mathrm{m}^{-3}$, was trapped during the period 1960 2010 (Ministry of Water Resources of China, 2010a). Another example is the Xiaolangdi Reservoir. During the first $10 \mathrm{yr}$ after its completion, approximately $2.83 \mathrm{~km}^{3}$ or $22.4 \%$ of its initial storage capacity was lost due to sedimentation (Ministry of Water Resources of China, 2010a).

Based on remote sensing data sets and hydrological records, Ran et al. (2013c) estimated reservoir sedimentation within the Yellow River basin. The average reservoir
Table 2. Sediment retention within the major mainstem reservoirs ${ }^{\mathrm{a}}$.

\begin{tabular}{lrrr}
\hline Reservoir & $\begin{array}{r}\text { Year of } \\
\text { completion }\end{array}$ & $\begin{array}{r}\text { Storage capacity } \\
\left(\mathrm{km}^{3}\right)\end{array}$ & $\begin{array}{r}\text { Sediment trapping } \\
(\mathrm{Gt})\end{array}$ \\
\hline Sanmenxia & 1960 & 9.64 & 8.6 \\
Qingtongxia & 1968 & 0.62 & $0.78^{\mathrm{b}}$ \\
Liujiaxia & 1969 & 5.7 & $2.2^{\mathrm{b}}$ \\
Longyangxia & 1986 & 24.7 & $0.4^{\mathrm{b}}$ \\
Wanjiazhai & 1998 & 0.9 & $0.31^{\mathrm{b}}$ \\
Xiaolangdi & 2000 & 12.65 & 3.68 \\
\hline
\end{tabular}

${ }^{a}$ Data are from Ministry of Water Resources of China, 2010a. ${ }^{\mathrm{b}}$ Sediment trapping is estimated up to the year 2005 .

sedimentation rate of all inventoried reservoirs was estimated at $0.59 \mathrm{Gt} \mathrm{yr}^{-1}$, and in total $19.32 \mathrm{Gt}$ of sediment was retained during the period 1950-2010. Particularly, most of the sediment was trapped in the large mainstem reservoirs (Table 2). Adding up the trapping contribution from the constructed silt check dams leads to a total sediment trapping of $40.3 \pm 1.2 \mathrm{Gt}$ (Ran et al., 2013c).

In addition to sediment trapping by dams, a huge quantity of sediment would be deposited in channels or on floodplains. Three major sediment sink zones in the Yellow River basin are the Ningxia-Inner Mongolian segment, the Fenwei graben, and the lower Yellow River reaches (Xu, 2005) (Fig. 1). The stored sediment within each sediment sink zone was calculated using Eq. (2). Based on the sedimentation rates in the three major sinks (Zhao, 1996; Xu, 2005), a total of $17.8 \pm 3.5 \mathrm{Gt}$ of sediment was deposited during the period 1950-2010, amounting to a sedimentation rate of $0.29 \pm 0.06 \mathrm{Gt} \mathrm{yr}^{-1}$. 


\subsubsection{Sediment reduction by soil control measures}

Soil conservation efforts have been made on hillslopes since the late 1950s. The commonly adopted measures include construction of terraces, reforestation, and grass planting (Ran et al., 2013b). However, the soil erosion intensity did not see significant reductions until the 1970s when massive soil control practices were conducted and since then, the sediment yield has sharply decreased (Zhao, 1996).

By dividing the middle Yellow River basin into four subcatchments, Ran (2007) studied the effects of each soil control measure conducted during the period 1970-1996. The three slope measures mentioned above had collectively retained $3 \pm 0.7 \mathrm{Gt}$ of sediment by 1996. Starting from 1999 , the Grain for Green Project that returns cropland to forest or grassland was launched on the Loess Plateau. Huge areas of cropland have been converted and as a result, the previously damaged vegetation has been greatly restored (Fu et al., 2011). By using the USLE model, the accumulatively controlled soils, due to vegetation recovery during the past decade, was estimated at $1.3 \pm 0.4 \mathrm{Gt}$ (Fu, unpublished data). In addition, as most adaptable hillslopes were converted into terraces before the 1990s, the total terrace area has remained largely unchanged since then (Ran et al., 2012). Hence, the soil erosion control rate of terraces can be assumed to be the same as before the 1990s. Accordingly, about $0.8 \mathrm{Gt}$ of soil was intercepted after 1996 by terraces. Adding up the controlled soils before 1970 by slope control measures and that during the period 1997-2010 (Kang et al., 2010; Zhao, 1996), and the estimate for 1970-1996, the total reduced sediment by slope soil control measures amounted to $6.0 \pm 1.1 \mathrm{Gt}$ during the $61 \mathrm{yr}$.

\subsubsection{Sediment loss through water diversion}

The annual water diversion has increased steadily over the study period 1950-2010. For example, the mean annual water diversion has doubled to $27.5 \mathrm{~km}^{3} \mathrm{yr}^{-1}$ for the period 2000-2008 from the level of $13.8 \mathrm{~km}^{3} \mathrm{yr}^{-1}$ during the period 1952-1959. The excessive water diversion has caused the lower reaches near the river mouth to suffer from continuing periods of interrupted water flow since 1972 (Liu and Xia, 2004). This phenomenon did not end until recently, when the central government intervened to execute a stricter water diversion quota.

As a result of water withdrawal, for the mainstem channel from Huayuankou to Lijin (Fig. 1), the mean rate of diverted sediment increased from $0.055 \mathrm{Gtyr}^{-1}$ during the period $1950-1959$ to $0.131 \mathrm{Gt} \mathrm{yr}^{-1}$ during the period $1980-1990$ (Hu et al., 2005). It then gradually decreased to $0.056 \mathrm{Gt} \mathrm{yr}^{-1}$ during the period 2000-2010 (Hu et al., 2008; Ministry of Water Resources of China, 2010a). Overall, the diverted sediment from the Yellow River mainstem channel was estimated at $10.5 \pm 0.4 \mathrm{Gt}$ over the $61 \mathrm{yr}$. Approximately $6 \mathrm{Gt}$ was diverted from the Huayuankou-Lijin reaches; $4.3 \mathrm{Gt}$ from the Lanzhou-Huayuankou reaches; and the remaining $0.2 \mathrm{Gt}$ from the channel above Lanzhou.

\subsubsection{Seaward sediment flux}

Suspended sediment discharge into the Bohai Sea has been measured at Lijin since 1950 (Fig. 3). During the period 1950-1968, human activities were relatively limited. Except for the commission of Sanmenxia Reservoir in 1960, there was no other large-scale dam construction and implementation of soil control practices. Water diversion was also significantly reduced, as severe soil salinization in the irrigated cropland occurred after excessive flood irrigation during the period 1959-1961. As a result, the sediment flux into the ocean averaged $1.24 \mathrm{Gt} \mathrm{yr}^{-1}$ during this period.

In the following decades, the sediment flux decreased gradually due to soil control measures, dam trapping, and enhanced water diversion. The average sediment flux during the period $1969-1986$ was $0.8 \mathrm{Gt} \mathrm{yr}^{-1}$, accounting for $64.5 \%$ of that during the period 1950-1968. After the joint operation of Longyangxia and Liujiaxia reservoirs in 1986, more sediment has been deposited within the landscape as a result of altered flow dynamics. The mean sediment flux during the period $1987-2000$ declined to $0.39 \mathrm{Gt} \mathrm{yr}^{-1}$. As of 2000 , with the operation of the Xiaolangdi Reservoir, which has a storage capacity for sedimentation of $7.55 \mathrm{~km}^{3}$, the mean sediment flux has further declined to $\sim 0.15 \mathrm{Gt} \mathrm{yr}^{-1}$. Current sediment flux represents only $12.1 \%$ of that during the period 1950-1968, which is largely the result of anthropogenic impacts (Miao et al., 2011). The cumulative suspended sediment load into the ocean is $44.8 \pm 1.9 \mathrm{Gt}$ over the $61 \mathrm{yr}$.

Besides the suspended load, the river also carries bed load simultaneously. However, obtaining accurate bed load transport flux is notoriously difficult. In many cases, the bed load fraction is taken to be a fixed fraction of the suspended load (Boateng et al., 2012). Assuming that the bed load accounts for $10 \%$ of the suspended load, the mean bed load into the ocean during the period $1950-2010$ is $4.48 \mathrm{Gt}$. As this study is focused on the sediment budget over a long timescale, both the suspended load and bed load are supposed to be derived from soil erosion. Together, the total seaward sediment load is around $49.3 \pm 2.1 \mathrm{Gt}$ during the period 1950-2010.

\subsubsection{Hillslope redistribution}

Unlike other sediment pathways where sediment destination could be clearly defined, it is hard to explicitly illustrate where the locally redeposited sediments are stored. They may have been retained on hillslopes close to the eroding sites, or stored in colluvial deposits or valley bottoms. Here, all the locally redeposited sediments were referred to as hillslope redistribution for simplicity. When the aforementioned terms are defined, the redistributed hillslope sediment can be quantified from Eq. (1). A total of $10.3 \pm 24.9 \mathrm{Gt}$ over the $61 \mathrm{yr}$ indicates an annual redistribution rate of 


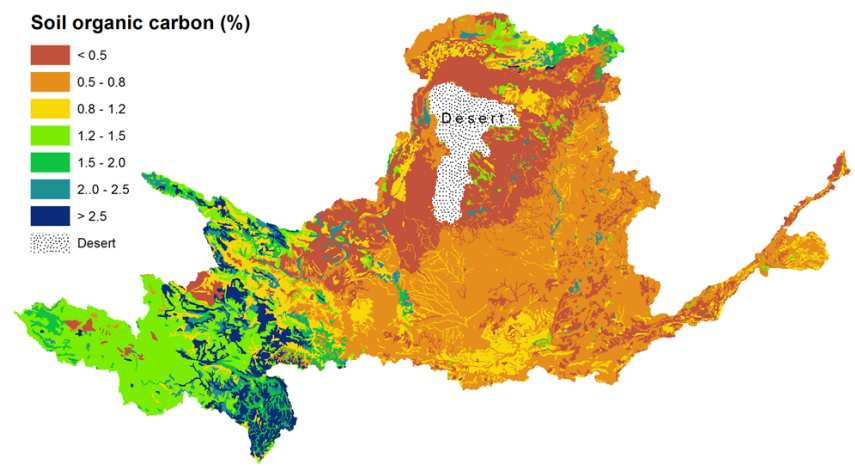

Fig. 4. Spatial variability of soil organic carbon in the Yellow River basin. Data are from the Environmental and Ecological Science Data Center for West China (http://westdc.westgis.ac.cn).

$0.17 \pm 0.41 \mathrm{Gt}$, comparable to the seaward sediment flux during the period 2001-2010 $\left(0.15 \mathrm{Gt} \mathrm{yr}^{-1}\right)$. Moreover, it demonstrates that the sediment delivery ratio (SDR) from hillslopes to the Yellow River mainstream is about 0.9, which is in good agreement with the high SDR previously estimated, while significantly higher than the global mean of 0.1 (Zhao, 1996; Walling and Fang, 2003).

\subsection{Associated organic carbon budget}

A soil map provided by the Environmental and Ecological Science Data Center for West China (http://westdc.westgis. ac.cn) was used to estimate SOC. The map is based on the second national soil survey conducted since 1979 by the Institute of Soil Science, Chinese Academy of Sciences. The spatial resolution for each raster grid is $1 \times 1 \mathrm{~km}^{2}$. The SOC content for each soil profile was compiled in two depths, including the topsoil $(0-30 \mathrm{~cm})$ and the subsoil $(30-100 \mathrm{~cm})$. The Yellow River basin is covered by 9123 polygons, with each including one soil profile. Given that the SOC content decreases with depth, only the SOC content of the topsoil horizon where erosion occurs is considered. Soil erosion affects not only the OC cycling in the mobilized soils, but also the SOC dynamics of the eroding and depositional environments due to the lateral OC fluxes (Harden et al., 1999; Van Oost et al., 2008). For example, the removed SOC at uplands would be dynamically replaced with new photosynthate (Berhe et al., 2007). Owing to severe soil erosion and land degradation, SOC replacement in the Yellow River basin is quite low, though the SOC pool may have slightly increased with continuous soil conservation (see discussion below). Although we cannot suppose that the SOC is in a steady state with time, we assume the SOC map represents the average SOC replacement dynamics over the period because the soil survey was conducted in the middle of the period 19502010. This assumption also applies to the depositional sites, whereby the OC amounts are estimated based on the average of the $61 \mathrm{yr}$-long period and not in a steady state.
Soil organic carbon in the topsoils is considerably low and shows strong spatial variability (Fig. 4). Due to OC input from plant residues, mainly alpine meadow, the headwater areas have a relatively higher SOC content than the loess regions. In some places on the eastern edge of the QinghaiTibetan Plateau where precipitation is $800 \mathrm{~mm} \mathrm{yr}^{-1}$, the SOC content can reach up to $39 \%$. In contrast, approximately $70 \%$ of the middle reaches show a SOC content of below $0.8 \%$, in particular in the regions around the desert where the SOC content is mostly $<0.5 \%$. Ran et al. (2013c) analyzed the spatial variability of soil erosion and sediment yield by generating a sediment yield map through spatial interpolation. The two maps were overlaid to account for the SOC content of sediment from major erosion areas. The basin-wide SOC content $\left(\theta_{E}\right)$ was averaged to $0.84 \pm 0.12 \%$ based on the SOC map (Fig. 4) using a sampling density of $1 \times 1 \mathrm{~km}^{2}$. Because the light SOC fraction will be preferentially removed, the eroded soils will be enriched in SOC (Quinton et al., 2010). The enrichment ratio, defined as the ratio of the SOC content in the eroded soils to that in the parent soils, is introduced to quantify the magnitude of enrichment. It can vary from $<1$ to larger than 5 , depending on several factors, including erosion intensity, soil particle size, and sediment concentration (Z. Wang et al., 2010).

For the Yellow River basin, owing to high erosion intensity and rapid water transport, the $\mathrm{OC}$ enrichment ratio is relatively low, usually less than 1.2 (Wang et al., 2008). An enrichment ratio of 1.1 was used to estimate the eroded OC from the topsoils. Furthermore, given that the sediments from gully erosion represent $\sim 50 \%$ of the total (Xu, 1999; Zhao, 1996; Jing et al., 1998) and the lower SOC content of the subsoils relative to the topsoils (Wang et al., 2008; Feng et al., 2013), the enrichment ratio for half of the eroded soils from the subsoils was estimated at 0.8. The total eroded SOC was estimated at $1.07 \pm 0.15 \mathrm{Gt}$ during the period 1950-2010.

By analyzing sediment samples collected near the estuary, at Lijin for example, the riverine OC transport from the Yellow River can be estimated (Wang et al., 2012; Cauwet and Mackenzie, 1993). Due to the high turbidity, its dissolved OC flux is very low as mentioned earlier (Zhang et al., 1992), which is in contrast to global OC transport that is roughly equally divided between the dissolved and particulate fractions (Ludwig et al., 1998; Stallard, 1998). Compared with the global average of $2.1 \%$ (Smith et al., 2001), the OC content of the Yellow River sediment mostly falls into the range of $0.37-0.8 \%$ (Table 3 ). The seaward sediment OC content $\left(\theta_{\mathrm{O}}\right)$ was estimated at $0.51 \pm 0.28 \%$ by calculating the average and the uncertainty range. The total transported OC into the ocean was $0.251 \pm 0.138 \mathrm{Gt}$ over the $61 \mathrm{yr}$.

Liu and Zhang (2010) explored the spatial and temporal variations of $\mathrm{OC}$ in the Yellow River by sampling from the headwaters to the river mouth. For the reaches below Lanzhou (Fig. 1), they discovered that the sediment OC content remained fairly stable, in the range of $0.44-0.85 \%$, particularly in the water diversion reaches (Table 3). This 
Table 3. A summary of organic carbon content of different budget terms.

\begin{tabular}{|c|c|c|c|c|}
\hline Soils/sediment & Used OC (\%) & $\begin{array}{l}\mathrm{OC}(\%) \text { in } \\
\text { literature }\end{array}$ & Source & Note \\
\hline Soils $\left(\theta_{E}\right)$ & $0.84 \pm 0.12$ & $0.21-39$ & $\begin{array}{l}\text { Environmental and Ecological } \\
\text { Science Data Center for West } \\
\text { China }\end{array}$ & $\begin{array}{l}\text { Estimated from the soil organic } \\
\text { carbon map. An enrichment ra- } \\
\text { tio of } 1.1 \text { for the topsoils and } \\
0.8 \text { for the subsoils was used. }\end{array}$ \\
\hline $\begin{array}{l}\text { Sediment deposited be- } \\
\text { hind all dams }\left(\theta_{T}\right)\end{array}$ & $0.65 \pm 0.19$ & & & $\begin{array}{l}\text { By taking into account the } \\
\text { OC content difference for sed- } \\
\text { iments trapped by silt check } \\
\text { dams and by reservoirs. }\end{array}$ \\
\hline Slope soil control $\left(\theta_{P}\right)$ & $0.84 \pm 0.12$ & & & $\begin{array}{l}\text { Assuming it has an OC content } \\
\text { similar to the parent soils. }\end{array}$ \\
\hline $\begin{array}{l}\text { Sediment diverted with } \\
\text { water }\left(\theta_{\mathrm{W}}\right)\end{array}$ & $0.51 \pm 0.28$ & & Liu and Zhang (2010) & $\begin{array}{l}\text { Similar to the seaward sedi- } \\
\text { ment. }\end{array}$ \\
\hline $\begin{array}{l}\text { Hillslope redistribution } \\
\left(\theta_{R}\right)\end{array}$ & $0.75 \pm 0.16$ & & & Average of $\theta_{E}$ and $\theta_{T}$ \\
\hline \multirow[t]{3}{*}{$\begin{array}{l}\text { Sediment deposited in } \\
\text { channels }\left(\theta_{H}\right)\end{array}$} & \multirow[t]{3}{*}{$0.49 \pm 0.29$} & $0.44-0.85$ & Liu and Zhang (2010) & \multirow{3}{*}{$\begin{array}{l}\text { For the mainstem channel } \\
\text { downstream of Lanzhou. } \\
\text { Mainly the middle-lower } \\
\text { reaches. } \\
\text { Based on a weekly sampling } \\
\text { frequency from Toudaoguai to } \\
\text { Lijin. }\end{array}$} \\
\hline & & $0.4-0.8$ & Z. Wang et al. (2007) & \\
\hline & & $0.11-0.89$ & Ran et al. (2013c) & \\
\hline \multirow[t]{4}{*}{$\begin{array}{l}\text { Seaward suspended } \\
\text { sediment }\left(\theta_{\mathrm{O}}\right)\end{array}$} & \multirow[t]{4}{*}{$0.51 \pm 0.28$} & $0.4-0.6$ & Zhang et al. (2009) & $\begin{array}{l}\text { Measurements for the fine sedi- } \\
\text { ments }(<16 \mu \mathrm{m} \text { in size }) \text { at Lijin } \\
\text { station. }\end{array}$ \\
\hline & & $0.37-0.79$ & Wang et al. (2012) & $\begin{array}{l}\text { Based on a monthly sampling } \\
\text { frequency at Lijin station. }\end{array}$ \\
\hline & & $0.42-0.5$ & Cauwet and Mackenzie (1993) & $\begin{array}{l}0.42 \text { in May (dry season) and } \\
0.5 \text { in August (wet season) near } \\
\text { the estuary. }\end{array}$ \\
\hline & & $0.15-0.75$ & Cai (1994) & $\begin{array}{l}\text { Calculated from } 115 \text { sediment } \\
\text { samples collected from the es- } \\
\text { tuary. }\end{array}$ \\
\hline
\end{tabular}

suggests that the diverted sediment has an approximately equivalent OC content as the seaward sediment. Thus, the OC content of the diverted sediment through water diversion $\left(\theta_{\mathrm{W}}\right)$ was assigned to be $0.51 \pm 0.28 \%$. The total diverted $\mathrm{OC}$ was estimated at $0.054 \pm 0.03 \mathrm{Gt}$ over the period. Likewise, the OC content for the sediment deposited in channels or on floodplains $\left(\theta_{H}\right)$ was assumed equivalent to that of the mainstem channel sediments. Because the coarse fraction with lower OC content was preferably deposited, $\theta_{H}$ was estimated at $0.49 \pm 0.29 \%$ (Table 3 ). The total deposited OC was about $0.087 \pm 0.054 \mathrm{Gt}$ during the period 1950-2010.

As stated earlier, soil erosion in the Yellow River basin is controlled by several heavy storms. During heavy storm events, the eroded soils can quickly reach the deposition sites after a short delivery. Except the readily decomposable labile fraction, it is likely that the eroded recalcitrant
OC has little chance to be mineralized and reworked (Quinton et al., 2010). On the Loess Plateau, this is highly possible given the strong carrying capacity of hyperconcentrated flows (Xu, 1999). The OC content of the sediments retained by silt check dams situated close to eroding sites is comparable to that of the eroded soils (Wang et al., 2008), and the OC content of the sediments trapped by reservoirs is more likely to be similar to that of the mainstem channel sediments, because most of these sediments are deposited in the mainstem reservoirs (Table 2). Therefore, the OC content of the sediments trapped by silt check dams $(\sim 21 \mathrm{Gt})$ and by reservoirs $(\sim 19.3 \mathrm{Gt})$ was $0.80 \pm 0.11 \%$ and $0.49 \pm 0.29 \%$, respectively. The mean OC content for the sediments trapped by all dams $\left(\theta_{T}\right)$ was estimated at $0.65 \pm 0.19 \%$, and the accumulated OC trapped by these dams during the period 1950-2010 was $0.262 \pm 0.077 \mathrm{Gt}$. 


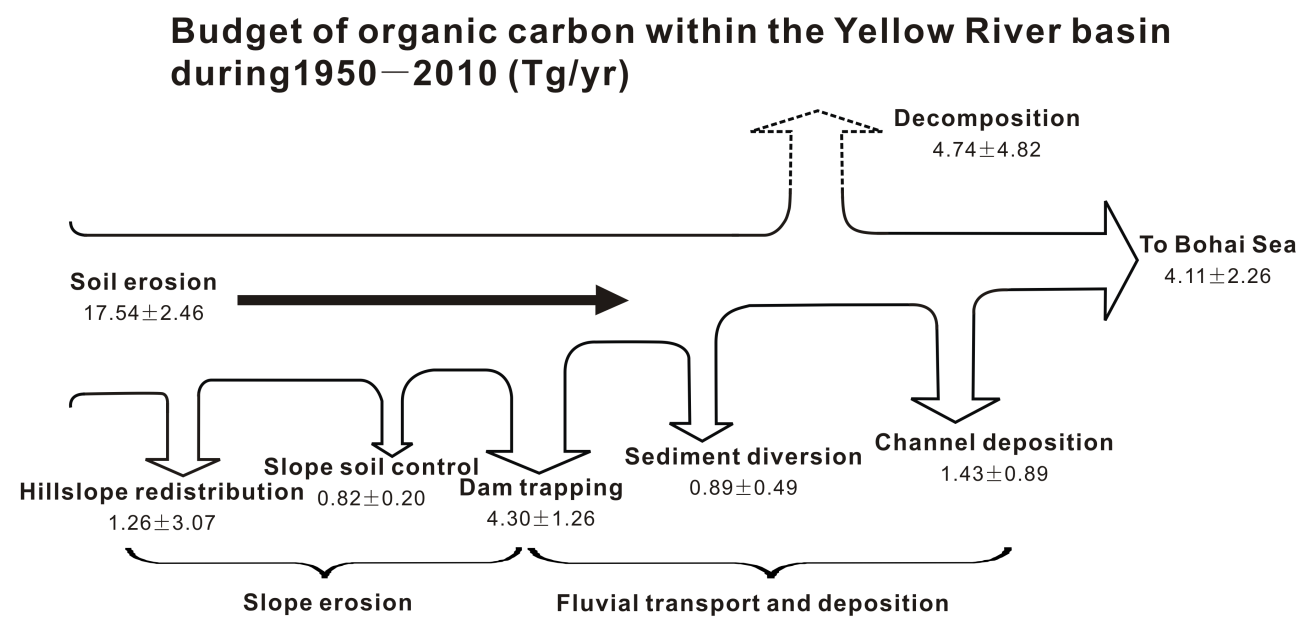

Fig. 5. Redistribution of the eroded organic carbon in the Yellow River basin during the period 1950-2010. The line widths of the arrows are approximately proportional to the average carbon fluxes.

On the Loess Plateau, the soil materials controlled by slope control measures are mostly fixed by the restored vegetation. For the Toudaoguai-Longmen reaches (Fig. 1), which supply $>75 \%$ sediment for the Yellow River, Ran et al. (2013b) analyzed the sediment reduction resulting from each measure. Due to widespread implementation, at least $70 \%$ of the soils stabilized by slope control measures are attributable to the restored vegetation. The soils stabilized by vegetation were assumed to have the same OC content as the noneroded topsoils (Chen et al., 2007). For the built terraces, crop planting, mainly potato, wheat, and maize, is pursued periodically. While tillage practices would accelerate OC decomposition, the planted crops are able to enhance SOC input through decaying litter, crop residues, and roots. Generally, agricultural activity represents an atmospheric $\mathrm{CO}_{2}$ sink (Smith et al., 2005; Van Oost et al., 2007). Thus, as for the built terraces, the OC content of the controlled soils is at least similar to, if not higher than, that of the noneroded topsoils. As such, the OC content of the soils controlled by all slope soil control measures $\left(\theta_{P}\right)$ was assumed to be $0.84 \pm 0.12 \%$ as in the noneroded topsoils with a low confidence. The total stored $\mathrm{OC}$ was estimated at $0.05 \pm 0.012 \mathrm{Gt}$.

Given that the locally redistributed sediments are mostly stored on hillslopes or valley bottoms, the associated OC content may be similar to that of the sediment trapped by dams. However, the associated OC is more likely to be oxidized because of enhanced exposure, compared with the sediments stored in anoxic environments as behind dams. On the other hand, these locally redistributed sediments transport over a relatively short distance and would soon be covered by subsequent sediment or protected by regrown plants. Their OC content should thus be comparable to that at the eroding sites. In this case, the average of the OC content of the two terms $\left(\theta_{T}\right.$ and $\left.\theta_{E}\right)$ was assumed to represent the OC content of the locally redistributed sediments. Therefore, $\theta_{R}$ was estimated at $0.75 \pm 0.16 \%$ (Table 3 ). With the estimated hillslope redistribution of sediment $(10.3 \pm 24.9 \mathrm{Gt})$, the corresponding OC redistributed was $0.077 \pm 0.187 \mathrm{Gt}$.

With determined OC for each sediment budget term, the decomposed OC can be quantified. Substituting the obtained OC estimates into Eq. (5) produced a decomposition of $0.289 \pm 0.294 \mathrm{Gt}$ over the $61 \mathrm{yr}$. Clearly, this estimate includes the propagation of uncertainty.

\section{Discussion}

\subsection{Summation of bulk sediment and organic carbon terms}

In large river basins with heterogeneous landscapes and strong human impacts, soil erosion at uplands and seaward transport are usually not in balance. For the Yellow River basin, home to 107 million people, the extent to which the eroded materials are deposited in the river system has depended increasingly on human activity since the 1970s (H. J. Wang et al., 2007). Redistribution of the eroded soils and OC for the period 1950-2010 is presented in Table 4. Dam trapping is the largest single term for the sediment on the landscape, and decomposition is the largest single term for the eroded OC. While the sediment diverted is nearly twofold that stabilized by slope soil control measures, the OC amounts of the two terms are roughly equivalent. The sediment and OC directly stabilized by human activities, including dam trapping, sediment diversion, and soil control measures, are $56.8 \pm 1.1 \mathrm{Gt}$ and $0.37 \pm 0.08 \mathrm{Gt}$, respectively, larger than the seaward fluxes. To better reflect the eroded OC cycling, Figure 5 shows the OC fluxes. Of the eroded OC of $17.54 \mathrm{Tg}$ every year, $4.74 \mathrm{Tg}$ is decomposed and another $4.3 \mathrm{Tg}$ is buried due to dam trapping, representing an important burial term. The OC stabilized by human activities 
is $6.01 \pm 1.37 \mathrm{Tg} \mathrm{yr}^{-1}, 1.5$ times higher than the seaward fluxes. Moreover, the vertical exchange (decomposition) is slightly higher than the lateral flux to the ocean.

Large-scale dam construction and implementation of numerous soil conservation projects on the Loess Plateau have greatly changed soil erosion and fluvial sediment and OC fluxes (Fig. 6). Over the $61 \mathrm{yr}$, approximately $63 \%$ of the eroded soils were deposited in the river system, and only $37 \%$ were discharged into the ocean. This sediment storage is significantly lower than that in the United States, where $90 \%$ of the sediment eroded off the land surface is stored somewhere in its river systems (Meade et al., 1990). In addition, human activities have directly stabilized $42.3 \%$ of the total (Fig. 6a). This higher storage relative to the seaward discharge illuminates the strong human impact on sediment redistribution on the landscape.

With respect to the OC, approximately $49.5 \%$ $(0.53 \pm 0.21 \mathrm{Gt})$ was buried in the river system and $23.5 \%$ $(0.25 \pm 0.14 \mathrm{Gt})$ was delivered into the ocean (Fig. 6b). The decomposed OC represents about $27 \%$ of the total eroded OC on average. Considering the fairly stable OC content along the mainstem channel, it indicates that the labile fraction has been largely oxidized before reaching the ocean. Thus, it can be concluded that approximately the labile fraction accounts for one-quarter of the total eroded OC, validating the commonly held assumption that about $20-40 \%$ of the displaced OC is mineralized (Davidson and Ackerman, 1993; Lal, 2003; Quinton et al., 2010; Berhe et al., 2007). Nevertheless, the obtained decomposition shows great uncertainty (Fig. 6b), suggesting the complexity in estimating the magnitude of OC decomposition. In contrast to the Yellow River characterized by low SOC $(0.84 \%)$, more OC is vulnerable to decomposition for river basins with high SOC content. In addition, the human-induced OC redistribution represents a total of $34.2 \%$ of the eroded OC (Fig. 6b), which is slightly larger than the decomposed fraction. Particularly, about half of the terrestrially redeposited OC $(49.4 \%)$ was buried behind dams, highlighting the importance of dams in sequestering the eroded OC. Without human activities, particularly silt check dams and slope soil control measures that are able to stabilize large amounts of sediment quickly after erosion, more OC would have been oxidized as transported en route to the ocean. Furthermore, the seaward OC flux would have been larger if no sediment was redisplaced in the river system by humans.

\subsection{Uncertainties of the sediment budget}

The soil erosion rate ranging between $1.7-2.5 \mathrm{Gt} \mathrm{yr}^{-1}$ with a mean of $2.2 \mathrm{Gt} \mathrm{yr}^{-1}$ was used to represent the basin-wide water erosion intensity over the $61 \mathrm{yr}$. Because of the coupled effects of climate change and human activity, the soil erosion rate has changed significantly over time. This can be seen from the temporally decreasing sediment load (Fig. 3). Given the temporal variability and the difficulty to assess the erosion for each year, we adopted the estimated soil erosion rate during the period prior to significant human activity (i.e., 1950-1970s; Table 1). This rate was then applied to analyze the redistribution of sediment and OC on the landscape, as well as the impact of human activity.

As mentioned earlier, the obtained hillslope redistribution amount includes sediment deposition processes not accounted for in the budget equation. Quantifying the channel sedimentation would have brought about certain errors (Hoffmann et al., 2009). With the completion of the Xiaolangdi Reservoir in 2000, a sediment flushing policy was introduced to mitigate channel sedimentation in the lower Yellow River (called "sediment regulation" in China). Manmade density flows are regularly released to flush downstream sediments deposited within the channel. The lower Yellow River has reversed from originally being a sediment sink to a net scour (H. J. Wang et al., 2007). Therefore, the actual channel sedimentation amount in this reach should be smaller than that estimated. Additionally, simplification in the estimate method would have underestimated the channel deposition because the full depositional length of the mainstem channel and its tributaries was not considered. A large number of tributary floodplains are important sinks of sediment and thus the associated OC (Hoffmann et al., 2007, 2013b).

Sediment transported by wind could increase the channel deposition. Input of windblown sands into the Yellow River occurs mainly in the Ningxia-Inner Mongolian segment (Fig. 1). A recent investigation shows that the windblown sand transport is $0.02 \mathrm{Gt} \mathrm{yr}^{-1}$ (Ta et al., 2008), which is small relative to the estimated erosion rate of $1.7-2.5 \mathrm{Gt} \mathrm{yr}^{-1}$. Contributions of windblown sand input to the total eroded soils are not significant in comparison with water erosion. This can also be validated from the high hillslope SDR. If the windblown sand input is quite high, the obtained SDR based on water erosion would be greatly reduced. In addition to the terms determined with a range, the sediment amount trapped by dams may bring some degree of uncertainty, given the large number of dams and the difficulty in estimating their respective trapping efficiency (Ran et al., 2013c). In general, the greatest uncertainty associated with the sediment budget is in the total eroded soils, which directly determines the redistribution pattern of sediment among the considered terms. Being dependent on the used soil erosion rates, as other budget terms are relatively well constrained, the hillslope redistribution term varies widely. This is particularly true because this term also includes the propagation of uncertainty.

When the maximum erosion rate of $2.5 \mathrm{Gt} \mathrm{yr}^{-1}$ is used, the accumulated sediment redistributed on the hillslopes could be $35 \mathrm{Gt}$ (Table 4). However, even with the used $2.5 \mathrm{Gt} \mathrm{yr}^{-1}$, the actual erosion amount may have been underestimated. Because the eroded soils from stream bank collapse are difficult to determine through conventional methods, they are usually excluded in the cited total erosion rates (Valentin et al., 2005). Based on the mean sediment load at Huayuankou 
Table 4. Redistribution of the eroded soils and organic carbon in the Yellow River basin during the period 1950-2010.

\begin{tabular}{|c|c|c|c|}
\hline Term & Sediment (Gt) & $\mathrm{OC}(\mathrm{Gt})$ & Note \\
\hline Soil erosion & $134.2 \pm 24.7$ & $1.07 \pm 0.15$ & $\begin{array}{l}\text { Based on a mean soil erosion rate of } 2.2 \mathrm{Gt} \mathrm{yr}^{-1} \text {; high confi- } \\
\text { dence for SOC. }\end{array}$ \\
\hline Dam trapping & $40.3 \pm 1.2$ & $0.262 \pm 0.077$ & $\begin{array}{l}\text { Sediment sum of reservoir trapping and silt check dam intercep- } \\
\text { tion; low confidence for OC. }\end{array}$ \\
\hline Channel deposition & $17.8 \pm 3.5$ & $0.087 \pm 0.054$ & $\begin{array}{l}\text { Sum of sediment deposits in three sediment sink zones; } \\
\text { medium-to-high confidence for OC. }\end{array}$ \\
\hline Sediment diversion & $10.5 \pm 0.4$ & $0.054 \pm 0.03$ & Based on mainstream water diversion; high confidence for OC. \\
\hline Seaward transport & $49.3 \pm 2.1$ & $0.251 \pm 0.138$ & $\begin{array}{l}\text { Based on measurements at Lijin station; high confidence for } \\
\text { OC. }\end{array}$ \\
\hline Slope soil control & $6.0 \pm 1.1$ & $0.05 \pm 0.012$ & $\begin{array}{l}\text { Sum of vegetation restoration and terrace formation; low confi- } \\
\text { dence for OC. }\end{array}$ \\
\hline Hillslope redistribution & $10.3 \pm 24.9$ & $0.077 \pm 0.187$ & $\begin{array}{l}\text { Determined as a residual, and includes the propagation of un- } \\
\text { certainty. }\end{array}$ \\
\hline Decomposition & - & $0.289 \pm 0.294$ & $\begin{array}{l}\text { Determined as a residual, and includes the propagation of un- } \\
\text { certainty. }\end{array}$ \\
\hline
\end{tabular}
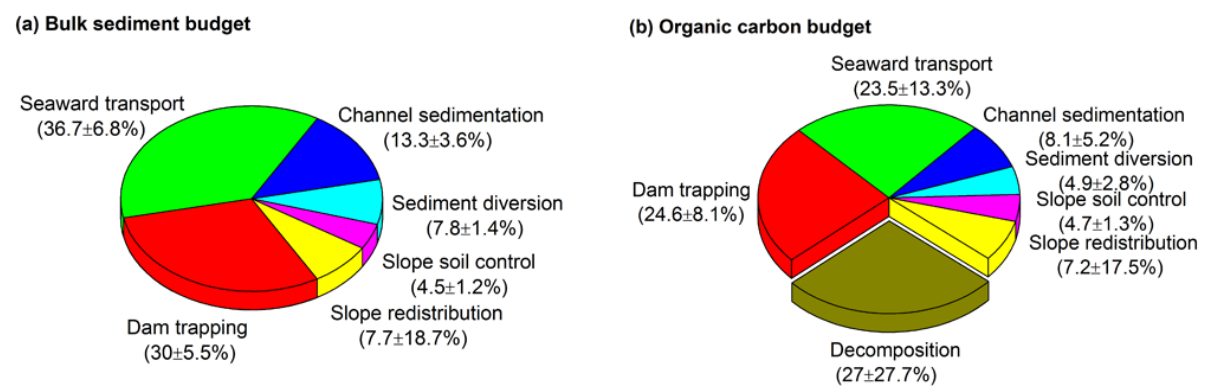

Fig. 6. Pie charts summarizing the redistribution of the bulk sediment (a) and organic carbon (b), based on the erosion rate of $2.2 \mathrm{Gt}^{\mathrm{yr}}{ }^{-1}$ with $1.7-2.5 \mathrm{Gt} \mathrm{yr}^{-1}$ for the consideration of uncertainty.

$\left(1.5 \mathrm{Gt} \mathrm{yr}^{-1}\right)$ and a global mean SDR of 0.1 (Walling and Fan, 2003), the extreme soil erosion rate is assumed to be $15 \mathrm{Gt} \mathrm{yr}^{-1}$. Using this erosion rate, hillslope redistribution will be the largest term, indicating the importance of hillslope storage as observed in central Europe (Hoffmann et al., 2013b).

\subsection{Uncertainties of the organic carbon budget}

\subsubsection{Uncertainties from the sediment budget}

Based on the erosion rate of $2.2 \mathrm{Gt} \mathrm{yr}^{-1}$, decomposition $\left(0.289 \mathrm{Gt}\right.$ or $\left.4.74 \mathrm{Tg} \mathrm{yr}^{-1}\right)$ over the period represents the largest single $\mathrm{C}$ redistribution term (Fig. 5). Nevertheless, the total decomposed OC would have been underestimated due to the difficulty in further determining the sediment budget terms. For example, a certain proportion of the OC diverted with water would also be decomposed due to dredging and remobilization. To maintain water delivery efficiency, irrigation canals in the river basin are regularly dredged and the deposited sediments are excavated to adjacent banks. Some of the OC buried with deposited sediments is likely to be oxidized under aerobic conditions after remobilization.
Carbon that is protected physically by aggregation or buried in alluvial or colluvial sites is also vulnerable to further human disturbances (Berhe et al., 2007). The floodplains along the Yellow River mainstem channel are usually used as croplands. While the conventional tillage techniques and resultant enhanced exposure of deep sedimentary OC to the surface would accelerate the decomposition rate of otherwise stabilized OC, the residual plant litter is able to increase the OC pool of the deposited sediments. If half of the calculated channel deposition is deposited on floodplains, the buried OC in canals and on floodplains is about $0.1 \mathrm{Gt}$ in total, or $9 \%$ of the eroded OC. Although unlikely, it is obvious that even complete oxidization of these remobilized OC could not significantly affect the OC redistribution results.

Similar to the sediment budget, the magnitude of soil erosion dictates the redistribution pattern of the eroded OC. Higher soil erosion will cause higher hillslope redistribution. Because the OC content for the locally redistributed sediment is indirectly estimated from the eroding soils and dam trapping terms (Table 3), uncertainties deriving from the sediment budget would influence the OC amount of the hillslope redistribution. Furthermore, the decomposition term would 
also be affected. For instance, the decomposition proportion will increase to $32 \%$ if the erosion rate of $2.5 \mathrm{Gt} \mathrm{yr}^{-1}$ is used. Owing to the great variability in erosion intensity and SOC, the decomposed OC flux varies greatly (Fig. 5). Thus, our estimate of OC decomposition is preliminary. A better constraint on the erosion rate and the sediment budget terms (e.g., channel deposition, Hoffmann et al., 2009) will improve the $\mathrm{OC}$ budget. Using the extreme erosion rate of $15 \mathrm{Gtyr}^{-1}$, for example, the decomposed OC could be $19.5 \mathrm{Tg} \mathrm{yr}^{-1}$.

\subsubsection{Uncertainties from the organic carbon terms}

Accuracy of the carbon budget is also determined by the selected OC content of the considered terms. Given the spatial and temporal heterogeneity of erosion, transport, and deposition across the basin, the budget results are with high uncertainties by nature. As the total eroded OC was estimated from the SOC map based on ground-based surveys, we adopted the value with a high confidence (Table 4). Likewise, because the OC content of the mainstem sediment has been repeatedly investigated and remained largely stable over time (Table 3), it is expected that the contents for the seaward export and sediment diversion terms are with high confidence. Because the coarse sediment is preferably deposited, the lower OC content for the sediment deposited in channels relative to the sediment that enters the ocean is with a medium-to-high confidence. For the sediment deposited in dams and controlled by soil control measures, however, the contents are proposed with a low confidence, as few data are currently available. Furthermore, given that information on the enrichment ratio for the sediments from gullies is lacking, the adopted 0.8 is possibly with a medium-to-low confidence.

Compared with SOC, the lower seaward sediment OC indicates a fraction of the eroded OC has been lost during the delivery process. From another perspective, the fairly stable sediment OC along the mainstem channel (Liu and Zhang, 2010) implies that decomposition is mainly confined to the initial transport stage before the $\mathrm{OC}$ reaches the mainstream. As the labile $\mathrm{OC}$ fraction is considerably vulnerable to degradation, it could be decomposed quickly following erosion. Given the long distance allowing for the labile OC to be fully mineralized before reaching the mainstream, it is easy to understand the stable but lower OC content. For the sediments trapped by dams, though the aerobic decomposition rate may be low, prevalence of anaerobic conditions would accentuate methanogenesis, leading to $\mathrm{CH}_{4}$ evasion. Consequently, the buried OC would not be totally protected. Some of it may be mineralized instead, and the rate depends on ambient environmental conditions. Overall, the buried OC with sediments deposited behind dams or in channels may have been overestimated somewhat, which requires further studies regarding anaerobic $\mathrm{C}$ transformation.
In terms of the seaward sediment and OC fluxes, they are based on the measurements at Lijin that is located $\sim 110 \mathrm{~km}$ upstream of the river mouth. Huge amounts of sediment would be deposited in the estuary and delta zones, and would not actually reach the Bohai Sea (H. J. Wang et al., 2007). The deposited OC in these zones would further be oxidized due to strong flow turbidity (Chen et al., 2012). Consequently, both the sediment and OC amounts that actually enter the ocean should be smaller than the determined.

\subsection{Implications of organic carbon emission}

During the soil erosion processes, detachment of soil particles will expose SOC that is initially encapsulated within aggregates and clay domains to microbial degradation (Lal and Pimentel, 2008). Fine soil materials and light SOC are preferentially transported away from the eroding sites to low-lying depressional locations where they would be sequestered. As for the detachment, transport, and deposition, the first two processes are likely to increase OC oxidation. The depositional process could protect SOC from mineralization, as the SOC eroded from soil surface is buried under a thick layer of fresh sediment. However, it is arbitrary to claim that soil erosion will necessarily result in a net $\mathrm{C}$ source or sink (Van Oost et al., 2008; Hoffmann et al., 2013a).

Though the lost $\mathrm{OC}$ at eroding sites can be partly replenished by enhanced C stabilization as stated above (Van Oost et al., 2008; Harden et al., 1999), this is likely difficult to occur on the Loess Plateau as a result of its extraordinarily severe soil erosion ( $\mathrm{Li}$ et al., 2007). Feng et al. (2013) investigated the Loess Plateau's ecosystem carbon storage dynamics and discovered its ecosystem had been a $\mathrm{C}$ source until 2000 when national vegetation restoration programs were launched. They found that the annual net ecosystem productivity was $-0.011 \mathrm{Gt}$ in 2000 and it had increased only in recent years. Hence, it can be concluded that the SOC replacement at uplands during the period 1950-2010 was very weak. Similarly, OC increment in the depositional lowlands resulting from ecosystem production was also limited during the period.

Although several uncertainties remain, the budget results provide a preliminary assessment of the OC redistribution after erosion. In view of the low SOC and the weak OC replacement at the eroding sites, it can be concluded that erosion-induced OC redistribution within the Yellow River basin during the period 1950-2010 likely represented a C source, emitting about $4.74 \mathrm{Tg} \mathrm{yr}^{-1}$ into the atmosphere, although a large proportion of OC was buried. However, given the great variability in the obtained decomposition and the inherent uncertainties in other budget terms, the erosioninduced $\mathrm{OC}$ cycle would be a $\mathrm{C}$ sink in extreme situations. If the enrichment ratio for the sediment from gully erosion is set to 0.5 and the estimates for other terms remain unchanged, closing the budget equation will lead to a negative decomposition value, indicating a $\mathrm{C}$ sink. 


\section{Conclusions}

A sediment budget for the Yellow River basin was constructed by considering the coupled processes of soil erosion at uplands, sediment deposition at low-lying sites and transport to the ocean. After the quantifiable terms were defined, the sediment amount redistributed on hillslopes was estimated. The obtained small hillslope redistribution corroborates the high SDR $(>0.9)$, indicating that most of the eroded soils are transported away from the eroding sites. In addition, soil erosion and sediment transport dynamics have been greatly affected by human activities during the period 1950-2010. Approximately $63 \%$ of the eroded soils were deposited in the river system, and only $37 \%$ were transported into the ocean.

In combination with the spatial variability of SOC and soil erosion, the total eroded OC during the period 1950-2010 was estimated at $1.07 \pm 0.15 \mathrm{Gt}$. Redistribution of the eroded OC was examined in relation to the associated sediment transport and deposition processes. Approximately 49.5\% of the eroded OC $(0.53 \pm 0.21 \mathrm{Gt})$ was buried in the river system, and $23.5 \%(0.25 \pm 0.14 \mathrm{Gt})$ was discharged into the ocean. Furthermore, half of the terrestrially redeposited OC was buried behind dams, indicating the importance of dams in sequestering the eroded OC. Closing the budget equation indicates that decomposition represents $27 \%$ of the total eroded OC, validating the commonly held assumption that about $20-40 \%$ of the displaced OC would be oxidized.

Despite several uncertainties to be more explicitly constrained, the budgetary results provide a means of assessing the redistribution of the eroded soils and OC within a watershed. Erosion-induced OC redistribution in the Yellow River basin during the period 1950-2010 likely represented a C source for the atmosphere. As human activities in the basin are becoming increasingly stronger, the resulting responses and related implications warrant further research to advance understanding of the erosion-induced sediment and carbon dynamics.

Acknowledgements. This study was supported by the National University of Singapore (MOE2011-T2-1-101). We are grateful to the Yellow River Conservancy Commission for access to the hydrological data, and the Environmental and Ecological Science Data Center for West China for the soil data set. This manuscript was greatly improved by comments from Thomas Hoffmann, Brian Bergamaschi, Zhengang Wang, and an anonymous reviewer.

Edited by: B. A. Bergamaschi

\section{References}

Aufdenkampe, A. K., Mayorga, E., Raymond, P. A., Melack, J. M., Doney, S. C., Alin, S. R., Aalto, R. E., and Yoo, K.: Riverine coupling of biogeochemical cycles between land, oceans, and atmosphere, Front. Ecol. Environ., 9, 53-60, doi:10.1890/100014, 2011.

Battin, T. J., Luyssaert, S., Kaplan, L. A., Aufdenkampe, A. K., Richter, A., and Tranvik, L. J.: The boundless carbon cycle, Nature Geosci., 2, 598-600, 2009.

Berhe, A. A., Harte, J., Harden, J. W., and Torn, M. S.: The significance of the erosion-induced terrestrial carbon sink, Bioscience, 57, 337-346, doi:10.1641/b570408, 2007.

Boateng, I., Bray, M., and Hooke, J.: Estimating the fluvial sediment input to the coastal sediment budget: A case study of Ghana, Geomorphology, 138, 100-110, 2012.

Cai, D.: Geochemical studies on organic carbon isotope of the Huanghe River (Yellow River) estuary, Sci. China Ser. B, 37, 1001-1015, 1994.

Cauwet, G. and Mackenzie, F. T.: Carbon inputs and distribution in estuaries of turbid rivers: the Yang Tze and Yellow rivers (China), Marine Chemistry, 43, 235-246, 1993.

Chen, C.-T. A., Huang, T.-H., Fu, Y.-H., Bai, Y., and He, X.: Strong sources of $\mathrm{CO}_{2}$ in upper estuaries become sinks of $\mathrm{CO}_{2}$ in large river plumes, Curr. Opinion Environ. Sustain., 4, 179-185, 2012.

Chen, L. D., Gong, J., Fu, B. J., Huang, Z. L., Huang, Y. L., and Gui, L. D.: Effect of land use conversion on soil organic carbon sequestration in the loess hilly area, loess plateau of China, Ecol. Res., 22, 641-648, 2007.

Chen, Y.: A preliminary analysis of the processes of sediment yield in small catchment on the Loess Plateau, Geographical Res., 2, 35-47, 1983 (in Chinese).

Chu, Z. X., Zhai, S. K., Lu, X. X., Liu, J. P., Xu, J. X., and $\mathrm{Xu}, \mathrm{K}$. H.: A quantitative assessment of human impacts on decrease in sediment flux from major Chinese rivers entering the western Pacific Ocean, Geophys. Res. Lett., 36, L19603, doi:10.1029/2009gl039513, 2009.

Cole, J. J. and Caraco, N. F.: Carbon in catchments: connecting terrestrial carbon losses with aquatic metabolism, Mar. Freshwater Res., 52, 101-110, 2001.

Cole, J. J., Prairie, Y. T., Caraco, N. F., McDowell, W. H., Tranvik, L. J., Striegl, R. G., Duarte, C. M., Kortelainen, P., Downing, J. A., Middelburg, J. J., and Melack, J.: Plumbing the global carbon cycle: Integrating inland waters into the terrestrial carbon budget, Ecosystems, 10, 171-184, doi:10.1007/s10021-006-9013-8, 2007.

Davidson, E. A. and Ackerman, I. L.: Changes in Soil Carbon Inventories Following Cultivation of Previously Untilled Soils, Biogeochemistry, 20, 161-193, 1993.

Feng, X., Fu, B., Lu, N., Zeng, Y., and Wu, B.: How ecological restoration alters ecosystem services: an analysis of carbon sequestration in China's Loess Plateau, Scientific Reports, 3, 2846, doi:10.1038/srep02846, 2013.

Fu, B.: Soil erosion and its control in the loess plateau of China, Soil Use Manage., 5, 76-82, doi:10.1111/j.14752743.1989.tb00765.x, 1989.

Fu, B., Liu, Y., Lü, Y., He, C., Zeng, Y., and Wu, B.: Assessing the soil erosion control service of ecosystems change in the Loess Plateau of China, Ecol. Complex., 8, 284-293, 2011. 
Gan, W. B., Chen, H. M., and Hart, Y. F.: Carbon transport by the Yangtze (at Nanjing) and Huanghe (at Jinan) Rivers, People's Republic of China, in: Transport of Carbon and Minerals in Major World Rivers, Part 2, edited by: Degens, E. T., Kempe, S., and Soliman, H., Mitt. Geol. Paläontol. Inst. Univ. Hamburg, SCOPE/UNEP Sonderbd., 459-470, 1983.

Harden, J., Sharpe, J., Parton, W., Ojima, D., Fries, T., Huntington, T., and Dabney, S.: Dynamic replacement and loss of soil carbon on eroding cropland, Global Biogeochem. Cy., 13, 885-901, 1999.

Hassan, M. A., Church, M., Xu, J., and Yan, Y.: Spatial and temporal variation of sediment yield in the landscape: Example of Huanghe (Yellow River), Geophys. Res. Lett., 35, L06401, doi:10.1029/2008GL033428, 2008.

Hoffmann, T., Erkens, G., Cohen, K., Houben, P., Seidel, J., and Dikau, R.: Holocene floodplain sediment storage and hillslope erosion within the Rhine catchment, The Holocene, 17, 105-118, 2007.

Hoffmann, T., Glatzel, S., and Dikau, R.: A carbon storage perspective on alluvial sediment storage in the Rhine catchment, Geomorphology, 108, 127-137, 2009.

Hoffmann, T., Mudd, S. M., van Oost, K., Verstraeten, G., Erkens, G., Lang, A., Middelkoop, H., Boyle, J., Kaplan, J. O., Willenbring, J., and Aalto, R.: Short Communication: Humans and the missing C-sink: erosion and burial of soil carbon through time, Earth Surf. Dynam., 1, 45-52, doi:10.5194/esurf-1-452013, 2013a.

Hoffmann, T., Schlummer, M., Notebaert, B., Verstraeten, G., and Korup, O.: Carbon burial in soil sediments from Holocene agricultural erosion, Central Europe, Global Biogeochem. Cy., 27, 828-835, 2013b.

Hu, C., Wang, Y., Zhang, Y., Tong, Y., Shi, H., Liu, C., Fan, Z., Jayakumar, R., Zhou, Z., Xu, M., and Wu, D.: Case Study on The Yellow River Sedimentation, International Research and Training Center on Erosion and Sedimentation, Beijing, China, 1-132, 2005.

$\mathrm{Hu}, \mathrm{C}$., Chen, X., and Chen, J.: Spatial distribution and its variation process of sedimentation in Yellow River, J. Hydraul. Eng., 39, 518-527, 2008 (in Chinese).

Jing, K., Li, J., and Li, F.: Erosion yield from the middle Yellow River basin and tendency prediction, Acta Geographica Sinica, 53, 107-115, 1998 (in Chinese).

Kang, L., Zhang, S., Wei, Y., and Liu, X.: Review of the effects researches of soil and water conservation on sediment reduction in the middle reaches of the Yellow River, Sci. Soil Water Cons., 8, 111-116, 2010 (in Chinese).

Lal, R.: Soil erosion and the global carbon budget, Environ. Int., 29, 437-450, 2003.

Lal, R. and Pimentel, D.: Soil erosion: a carbon sink or source?, Science, 319, 1040-1042, 2008.

$\mathrm{Li}, \mathrm{Z}$. and Liu, B.: Calculation on soil erosion amount of main river basins in China, Sci. Soil Water Conservation, 4, 1-6, 2006 (in Chinese).

Li, Y., Zhang, Q. W., Reicosky, D. C., Lindstrom, M. J., Bai, L. Y., and $\mathrm{Li}, \mathrm{L}$. : Changes in soil organic carbon induced by tillage and water erosion on a steep cultivated hillslope in the Chinese Loess Plateau from 1898-1954 and 1954-1998, J. Geophys. Res., 112, G01021, doi:10.1029/2005JG000107, 2007.
Liu, C. M. and Xia, J.: Water problems and hydrological research in the Yellow River and the Huai and Hai River basins of China, Hydrol. Process., 18, 2197-2210, 2004.

Liu, D. and Zhang, L.: Temporal and spatial distributions of organic carbn in the Huanghe (Yellow) River, Periodical of Ocean Univeristy of China, 40, 105-110, 2010 (in Chinese).

Liu, D., Ding, Z., and Guo, Z.: Loess, Environment, and Global Change, Science Press, Beijing, China, 1991.

Ludwig, W., Amiotte-Suchet, P., Munhoven, G., and Probst, J. L.: Atmospheric $\mathrm{CO}_{2}$ consumption by continental erosion: presentday controls and implications for the last glacial maximum, Global Planet. Change, 17, 107-120, 1998.

Luo, X.-L., Zeng, E. Y., Ji, R.-Y., and Wang, C.-P.: Effects of inchannel sand excavation on the hydrology of the Pearl River Delta, China, J. Hydrol., 343, 230-239, 2007.

Meade, R. H., Yuzyk, T. R., and Day, T. J.: Movement and storage of sediment in rivers of the United States and Canada, in: The Geology of North America, vol. 1, Surface Water Hydrology, edited by: Wolman, M. G., and Riggs, H. C., Geological Society of America, Boulder, Colorado, 255-280, 1990.

Miao, C., Ni, J., Borthwick, A. G. L., and Yang, L.: A preliminary estimate of human and natural contributions to the changes in water discharge and sediment load in the Yellow River, Global Planet. Change, 76, 196-205, doi:10.1016/j.gloplacha.2011.01.008, 2011.

Ministry of Water Resources of China: Standard for Classification and Gradation of Soil Erosion SL 190-2007, China Waterpower Press, Beijing, China, 2008.

Ministry of Water Resources of China: China River Sediment Bulletin, China Waterpower Press, Beijing, China, 2010a.

Ministry of Water Resources of China: China Water Resources Bulletin, China Waterpower Press, Beijing, China, 2010b.

Qin, M. Z., Jackson, R. H., Yuan, Z. J., Jackson, M. W., and Sun, B. The effects of sediment-laden waters on irrigated lands along the lower Yellow River in China, J. Environ. Manage., 85, 858-865, 2007.

Quinton, J. N., Govers, G., Van Oost, K., and Bardgett, R. D.: The impact of agricultural soil erosion on biogeochemical cycling, Nature Geosci., 3, 311-314, 2010.

Ran, D.: Water and sediment variation and ecological protection measures in the Middle Reach of the Yellow River, Resour. Sci., 28, 93-100, 2007 (in Chinese).

Ran, D., Wu, Y., Li, X., Wang, F., and Shen, Z.: Analysis on contribution rate of water and sediment reduction by human activities at Hekouzhen-Longmen section in last years, Yellow River, 34 84-86, 2012 (in Chinese).

Ran, L. and Lu, X. X.: Delineation of reservoirs using remote sensing and their storage estimate: an example of the Yellow River basin, China, Hydrol. Process., 26, 1215-1229, 2012.

Ran, L., Lu, X. X., Sun, H., Han, J., Li, R., and Zhang, J.: Spatial and seasonal variability of organic carbon transport in the Yellow River, China, J. Hydrol., 498, 76-88, 2013a.

Ran, L., Lu, X. X., and Xu, J. C.: Effects of vegetation restoration on soil conservation and sediment loads in China: A critical review, Critical Rev. Environ. Sci. Technol., 43, 1-32, 2013b.

Ran, L., Lu., X. X., Xin, Z. B., and Yang, X.: Cumulative sediment trapping by reservoirs in large river basins: A case study of the Yellow River basin, Global Planet. Change, 100, 308-319, $2013 c$. 
Reich, P., Eswaran, H., and Beinroth, F.: Global dimensions of vulnerability to wind and water erosion, in: Sustaining the Global Farm. Selected papers from the 10th International Soil Conservation Organization Meeting, May 24-29, 1999, edited by: Stott, D. E., Mohtar, R. H., and Steinhardt, G. C., Perdue University and USDA-ARS National Soil Erosion Research Laboratory, 838846, 2001.

Schlünz, B. and Schneider, R. R.: Transport of terrestrial organic carbon to the oceans by rivers: re-estimating flux- and burial rates, Int. J. Earth Sci., 88, 599-606, 2000.

Shi, D.: Effects of soil erosion on ecological environment and natural disasters, Adv. Earth Sci., 4, 41-44, 1990 (in Chinese).

Smith, S. V., Renwick, W. H., Buddemeier, R. W., and Crossland, C. J.: Budgets of soil erosion and deposition for sediments and sedimentary organic carbon across the conterminous United States, Global Biogeochem. Cy., 15, 697-707, doi:10.1029/2000gb001341, 2001.

Smith, S. V., Sleezer, R. O., Renwick, W. H., and Buddemeier, R.: Fates of eroded soil organic carbon: Mississippi basin case study, Ecol. Appl., 15, 1929-1940, 2005.

Stallard, R. F.: Terrestrial sedimentation and the carbon cycle: Coupling weathering and erosion to carbon burial, Global Biogeochem. Cy., 12, 231-257, 1998.

Ta, W., Xiao, H., and Dong, Z.: Long-term morphodynamic changes of a desert reach of the Yellow River following upstream large reservoirs' operation, Geomorphology, 97, 249-259, 2008.

Taylor, J. R.: An Introduction to Error Analysis: The Study of Uncertainties in Physical Measurements, University Science Books, Sausalito, CA, 1997.

Valentin, C., Poesen, J., and Li, Y.: Gully erosion: Impacts, factors and control, CATENA, 63, 132-153, doi:10.1016/j.catena.2005.06.001, 2005.

Van Hemelryck, H., Govers, G., Van Oost, K., and Merckx, R.: Evaluating the impact of soil redistribution on the in situ mineralization of soil organic carbon, Earth Surf. Process. Landf., 36, 427-438, doi:10.1002/esp.2055, 2011.

Van Oost, K., Quine, T. A., Govers, G., De Gryze, S., Six, J., Harden, J. W., Ritchie, J. C., McCarty, G. W., Heckrath, G., Kosmas, C., Giraldez, J. V., da Silva, J. R. M., and Merckx, R.: The impact of agricultural soil erosion on the global carbon cycle, Science, 318, 626-629, 2007.

Van Oost, K., Six, J., Govers, G., Quine, T., and Gryze, S. D.: Response to "Soil erosion: a carbon sink or source?", Science, 319, 1042-1042, 2008.

Walling, D. E. and Fang, D.: Recent trends in the suspended sediment loads of the world's rivers, Global Planet. Change, 39, 111126, 2003.
Wang, F., Li, R., and Yang, Q.: Review on effects of human activities on the soil erosion in the Loess Plateau, J. Sediment Res., 5, 74-80, 2003 (in Chinese).

Wang, H. J., Yang, Z. S., Saito, Y., Liu, J. P., Sun, X. X., and Wang, Y.: Stepwise decreases of the Huanghe (Yellow River) sediment load (1950-2005): Impacts of climate change and human activities, Global Planet. Change, 57, 331-354, 2007.

Wang, X., Ma, H., Li, R., Song, Z., and Wu, J.: Seasonal fluxes and source variation of organic carbon transported by two major Chinese Rivers: The Yellow River and Changjiang (Yangtze) River, Global Biogeochem. Cy., 26, GB2025, doi:10.1029/2011gb004130, 2012.

Wang, Y., Zhang, X., and Han, F.: Profile variability of soil properities in check dams on the Loess Plateau and its functions, Environ. Sci., 29, 1020-1026, 2008 (in Chinese).

Wang, Y., Hu, C., and Shi, H.: Allocation and utilization of sediment resource in the Yellow River Basin, Sci. Soil Water Conservation, 8, 20-26, 2010 (in Chinese)

Wang, Z., Wang, W., and Tian, S.: Mineral composition and distribution of the sediment in the Yellow River basin, J. Sediment Res., 5, 1-8, 2007 (in Chinese).

Wang, Z., Govers, G., Steegen, A., Clymans, W., Van den Putte, A., Langhans, C., Merckx, R., and Van Oost, K.: Catchment-scale carbon redistribution and delivery by water erosion in an intensively cultivated area, Geomorphology, 124, 65-74, 2010.

$\mathrm{Xu}, \mathrm{J} .:$ Erosion caused by hyperconcentrated flow on the Loess Plateau of China, CATENA, 36, 1-19, 1999.

$\mathrm{Xu}, \mathrm{J}$.: Effect of sediment sink of lower Yellow River on grain size of sediment flux to the sea, J. Sediment Res., 6, 21-28, 2005 (in Chinese)

Yang, S. L., Zhang, J., Dai, S. B., Li, M., and Xu, X. J.: Effect of deposition and erosion within the main river channel and large lakes on sediment delivery to the estuary of the Yangtze River, J. Geophys. Res., 112, F02005, doi:10.1029/2006jf000484, 2007.

Zhang, L. J., Zhang, J., and Gong, M.: Size distributions of hydrocarbons in suspended particles from the Yellow River, Appl Geochem., 24, 1168-1174, 2009.

Zhang, S., Gan, W.-B., and Ittekkot, V.: Organic matter in large turbid rivers: the Huanghe and its estuary, Marine Chemistry, 38, 53-68, doi:10.1016/0304-4203(92)90067-k, 1992.

Zhao, W.: The Yellow River's Sediment, Yellow River Conservancy Press, Zhengzhou, China, 1996. 